\title{
Improving Senior High School Students' Physics Problem-solving Skills Through Investigated Based Multiple Representation (IBMR) Learning Model
}

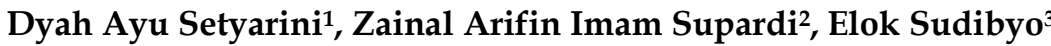

1,2,3 Science Education Postgraduate Program, Universitas Negeri Surabaya, Surabaya, Indonesia

\begin{tabular}{|c|c|}
\hline 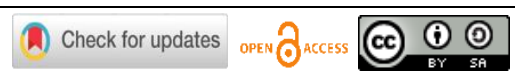 & DOI : https://doi.org/10.46245/ijorer.v2i1.74 \\
\hline Sections Info & ABSTRACT \\
\hline Article history: & This research aims to improve senior high school students' physics \\
\hline Submitted: December 20, 2020 & problem-solving skills through learning used IBMR learning model. This \\
\hline Final Revised: January 14, 2021 & research was a pre-an experimental study with a one-group pre-test and \\
\hline Accepted: January 14, 2021 & post-test design. The Methods of data collection used validation and test. \\
\hline Published Online: January 31, 2021 & The materials used to teach were valid category by two experts and can \\
\hline Keywords: & be used to practice physics problem-solving skills. The average post-test \\
\hline IBMR Learning Model & score physics problem-solving ability was 73.24 with an $\mathrm{N}$-gain of 0.59 \\
\hline Physics Problem-solving Ability & was classified as moderate. The success of IBMR learning model-based \\
\hline Senior High School Students & devices in practicing problem-solving abilities can be seen in the increase \\
\hline 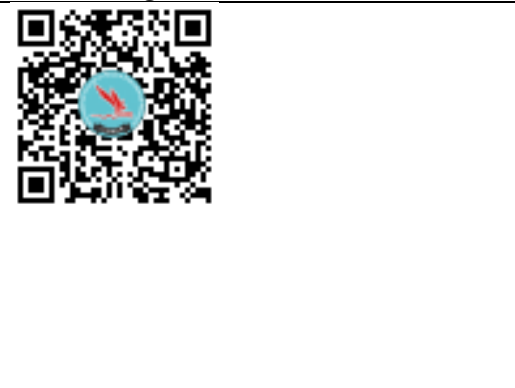 & $\begin{array}{l}\text { in the average score in each indicator of problem-solving abilities. The } \\
\text { indicator of understanding the problem had the highest post-test average } \\
\text { score of } 94.58 \text { with an N-gain of } 0.89 \text { in the high category. The problem- } \\
\text { solving indicator had the lowest posttest average score was } 58.22 \text { with N- } \\
\text { gain } 0.39 \text { and mean that it was the moderate category. Based on the } \\
\text { results study, it can be concluded that the learning used by IBMR } \\
\text { learning model can practice the ability to solve physics problems on heat } \\
\text { material and its displacement. Learning with the IBMR learning model } \\
\text { was expected to train students in solving physics problems. The stages in } \\
\text { the IBMR learning model can help students }\end{array}$ \\
\hline
\end{tabular}

\section{INTRODUCTION}

Physics is a natural science that comes from natural phenomena. Student being able to solve physics problems is one of the goals of learning physics. Physics problem- solving skills are an important part of the curiculum in Indonesia (Kemendikbud, 2016). Several studies argue the problem-solving physics is important goal in learning physics (Rojes, 2012; Gok, 2015; Hong et al., 2012; Doctor, 2015) because it is a students cognitive processes activity to building physics knowledge (Bogard et al., 2013; Docktor, 2016). If students can plan, organize, take action, evaluate, adopt and conclude students are said to master physics problem-solving ability (Erozka, 2013). Problem-solving is an important part of scientific reasoning because it has an effect on emotional, cognitive, and psychomotor enhancement and change (Alshamali \& Daher, 2016). Based on the facts above, it shows that problem-solving ability ia an important thing that must be developed in learning physics.

The achievement of students' abilities in applying their knowledge into new contexts, linking concepts, and developing the knowledge that students have into different contexts is an act of solving student problems (Kurniawan, 2014). Problem-solving skills are higher order thinking skills as a cognitive process to find solutions to a physical problem (Santrock, 2011). The cognitive ability of students in solution of 
Improving Senior High School Students' Physics Problem-solving Skills Through Investigated Based Multiple Representation (IBMR) Learning Model

physics problem in innovative ways is problem-solving based on students' cognitive views (Moreno, 2013). In solving physics problems, students apply the knowledge and abilities students have to achieve certain goals.

In the field of science, the ability of Indonesian students to solve physics problems is still low (Eriza, 2017). According the Survey For International Student Assessment (PISA), Indonesia in 50th place out of a total of 57 countries in solving questions. Based on TIMSS survey in 2011 published in 2012. Indonesia is ranked 40 out of 42 participating countries with an average score of 406 in science. Based on these results, Indonesian students only mastered routine questions and knowledge of daily facts (Rahmawati,2016). Based on these facts, can be said that Indonesian students still have difficulty work on various kinds of physics questions. The ability of students to absorb the knowledge they get in learning is the main supporting factor for students to solve physics problems (Azizah, 2015). Based on the fact, the low solution of problem physics, some of the causes are weak understanding of the concept of physics, the lack of teacher attention in the learning process to practice physics problem-solving skills, learning only focuses on solving problems that are quantitative in nature, causing students difficult to solve physics problems (Sujarwanto, 2014), the lack of student practicum activities, one of which is student physics problem-solving, is less trained (Aryawan, 2014). Lack of students in mathematical skills and understanding of the problem becomes an obstacle to students 'low physics problem-solving ability (Reddy and Panacharoensawad, 2017; Halim et al., 2016) Based on several causes of students' low ability to solve physics problems, in general it is due to the inability of students to absorb the knowledge they learn. because process acquiring knowledge is not carried out independently.

One of learning models developed to improve physics problem-solving skills is Investigation Based Multiple Representation (IBMR) learning model (Susanto et al., 2018). The IBMR learning model is designed as a physics learning model to teach representation skills and physics problem-solving. This model has five phases, namely: 1) orientation, 2) investigation, 3) multi-representation, 4) application, and 5) evaluation. The IBMR learning model applied to students in electrical circuit material is able to improve physics problem-solving abilities (Siswanto, 2017), physics learning using the IBMR learning model is able to improve the physics problem-solving abilities of class $\mathrm{X}$ very well. IBMR learning model was developed with the aim of being an intervention to increase the ability of representation to support students' physics problem-solving abilities, meaning that if students are able to represent students, they will can to solve physics problems (Siswanto et al., 2018; De Cock, 2012; Moeed, 2013).

The 2015 Survey For International Student Assesment (PISA) problem-solving framework recommends solving student problems, it should not only focus on the final solution, but on the process and understanding of students' concepts in determining suitable strategies to find solutions (OECD, 2015). Learning to develop students' problem-solving abilities can be done by implementing learning strategies that hold several principles in the 21st century, namely learning that is relevant and needed in real / contextual life (Glaze, 2018; Opfer, 2012). Learning with the IBMR learning model is the process of building student knowledge based on direct experience by presenting real-life problems that involve students in gaining knowledge with problem orientation, investigation, multi-representation, application, and evaluation. Problem-solving 
Improving Senior High School Students' Physics Problem-solving Skills Through Investigated Based Multiple Representation (IBMR) Learning Model

activities are divided into several indicators according to experts. The physics problemsolving indicator in this research consists of 4 steps, namely, 1) Understanding the problem 2) Planning a solution, 3) Implementing planning and 4) Evaluating.

This research purpose to explore the effectiveness of IBMR learning model-based device in training students' problem-solving abilities on heat material and its transfer. Through exploration of students' problem-solving abilities, researchers can find out the abilities students have in understanding and applying the concept of heat and its displacement to solve physics problems. The results of the study from the exploration of students 'physics problem-solving abilities on heat material and its transfer through the IBMR learning model can be important information for conducting further studies regarding student physics problem.

\section{RESEARCH METHOD}

The main problem this research is how the effectiveness of learning with the IBMR learning model to practice students' physics problem-solving skills. This research was categorized as R\&D (research and development) focuses on the quality of the application learning used tools that had developed and validated by two experts (content and construct validity). The stage of development in this research used a research design Plomp model. This model consists of five development phases, 1) preliminary investigation phase, 2) design phase, 3) realization/construction phase, 4) testing, evaluation, dan revision phase, and 5) implementation phase.

The development design can see in Figure 1.

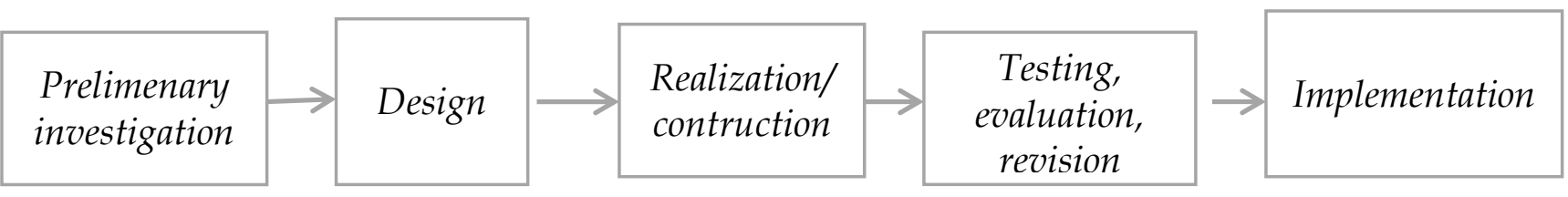

Figure 1. The Development Design Stage.

This research used a quantitative research design using a pre-experimental design, especially the one group pretest and posttest designs. The population in this research students senior high school grade 11. The technique of taking sample from the members of the population was random sampling without considering the strata in the population. The subjects of this study consisted of 30 students of class XI-MIPA 5 in a senior high school in Madiun Regency. Time of the research for the second semester of the 2020/2021 academic year. The data collection methods used were validation and test. The beginning of the study before being given learning treatment with the IBMR learning model, students were given a problem-solving test of four descriptive questions related to the heat material and its displacement as an initial test of students' physics problem solving abilities. At the second to fourth meeting, students are given treatment on heat material and its transfer is in the form of learning with the IBMR learning model. At the fifth meeting students were given a posttest by giving 4 questions in description with the same type of questions as the pre-test questions. The results of the research on students' physics problem solving abilities on the heat material and its displacement were then analyzed. 
Improving Senior High School Students' Physics Problem-solving Skills Through Investigated Based Multiple Representation (IBMR) Learning Model

\section{Analysis of Validation}

After the research process is carried out and data is collected, then the data analys technique is carried out. Researchers try to describe the results of their research. Data analysis to determine the effect of learning with the IBMR in this research as following: Measuring problem-solving abilities using descriptive analysis according to Setyono (2016), namely:

$$
\% \text { score }=\frac{\text { Average student score }}{\text { maximum student score }} \times 100 \%
$$

Table 1. Rating of problem-solving ability.

\begin{tabular}{ccc}
\hline Score interval & Percentage & Category \\
\hline $0-25$ & $0-25$ & Very low \\
\hline $26-49$ & $21-40$ & Low \\
\hline $59-73$ & $41-60$ & Enough \\
\hline $74-98$ & $61-80$ & High \\
\hline $99-122$ & $81-100$ & Very high \\
\hline & & (Setyono, 2016)
\end{tabular}

Data analysis prerequisite test to determine the effect of IBMR learning model on students' physics problem-solving skills in this research:

a. Normality test with the following hypotesis:

$\mathrm{H}_{0}$ : sig $\geq 0.05=$ Data fromthe populatiion are normally distributed

$\mathrm{H}_{1}$ : sig $\leq 0.05=$ Data from the population are not normally distributed

b. Paired sample t-test with the following hypothesis:

$\mathrm{H}_{0}: \mu_{1} \geq \mu_{2}$ ( IBMR learning model does not effect increasing students' physics problem-solving skills)

$\mathrm{H}_{1}: \mu_{1}<\mu_{2}$ (IBMR learning model affects increasing students' physics problemsolving skills)

\section{N-Gain Score}

This analysis is used to see whether the students' physics problem-solving abilities on heat and its transfer can be trained on students or not. This analysis was based on the students pre-test and post-test data after using the IBMR learning model-based learning tools, using the equation used by Hake (2002) as follows:

$$
N-\text { Gain }=\frac{S_{\text {post }}-S_{\text {Pre }}}{S_{\text {maks }}-S_{\text {pre }}}
$$

The criteria for increasing students' physics problem-solving abilities are based on the provisions in Table 2.

Table 2. Category N- gain Score

\begin{tabular}{cc}
\hline Gain Score & Category \\
\hline$(\mathrm{g}) \geq 0.7$ & High \\
\hline $0.3 \leq(\mathrm{g})<0.7$ & Moderate \\
\hline$(\mathrm{g})<0.3$ & Low \\
\hline
\end{tabular}

(Hake, 2002) 
Improving Senior High School Students' Physics Problem-solving Skills Through Investigated Based Multiple Representation (IBMR) Learning Model

\section{RESULTS AND DISCUSSION \\ Validation of Learning Materials}

The results of the average validity of teaching materials can be seen in Table 3.

Table 3. Average scores teaching materials validity.

\begin{tabular}{ccc}
\hline Name & Average Score Validity & Category \\
\hline Syllabus & 3.35 & Valid \\
\hline Lesson Plan (RPP) & 3.61 & Very valid \\
\hline Student's Worksheet & 3.47 & Valid \\
\hline Student's Textbook & 3.44 & Valid \\
\hline Physics Problem-solving Test & 3.41 & Valid \\
\hline
\end{tabular}

Based on data obtained, it shows the IBMR learning model-based teaching materials to practice physics problem-solving skills have a valid category so that the learning tools developed are feasible and can be used in the learning process to practice physics provlem solving skills by making a few revisions according to the validator's suggestions. This is in accordance with the theory of validation of teaching materials by Akbar (2013: 40) that teaching materials that are categorized as valid can be used in the learning process by making a few revisions according to the validator's suggestion.

\section{Learning Outcomes of Physics Problem-solving Ability}

The process of collecting data to knowing students' physics problem-solving abilities was carried out after the teaching materials were declared valid. Indicators of solving physics problems can be seen in Table 4.

Tabel 4. Indicators problem-solving ability.

\begin{tabular}{cl}
\hline Stage & \multicolumn{1}{c}{ Indicators } \\
\hline $\begin{array}{c}\text { Understand } \\
\text { the problem }\end{array}$ & $\begin{array}{l}\text { write down the known physical quantities in the problem, identify the problem } \\
\text { to be solved, and rewrite the problem in different forms (cite the problem, } \\
\text { draw a diagram or graph about the problem) and the factors or information } \\
\text { related to the problem }\end{array}$ \\
\hline $\begin{array}{c}\text { Planning } \\
\text { solution }\end{array}$ & $\begin{array}{l}\text { Identify and select concepts, principles or rules, formulas, laws, and physical } \\
\text { equations related to the problem }\end{array}$ \\
\hline $\begin{array}{c}\text { Apply the } \\
\text { known }\end{array}$ & $\begin{array}{l}\text { solve the problem by substituting the values into the planned equation } \\
\text { Evaluating }\end{array}$ \\
& $\begin{array}{l}\text { checking the suitability of the answer to the problem and checking the } \\
\text { quantities and units, checking again }\end{array}$ \\
\hline
\end{tabular}

Based on research result, it was obtained the ability to solve physics problems before learning was carried out with the IBMR learning model-based teaching materials and after learning with the IBMR teaching materials model according to Table 2 could be categorized as follows in Table 5.

Table 5. Pretest and posttest result.

\begin{tabular}{ccccc}
\hline & \multicolumn{2}{c}{ Pretest } & \multicolumn{2}{c}{ Posttest } \\
\hline Interval Score & Category & Amount & Category & Amount \\
\hline $0-25$ & Very Low & 0 & Very Low & 0 \\
\hline
\end{tabular}


Improving Senior High School Students' Physics Problem-solving Skills Through Investigated Based Multiple Representation (IBMR) Learning Model

\begin{tabular}{ccccc}
\hline & \multicolumn{2}{c}{ Pretest } & \multicolumn{2}{c}{ Posttest } \\
\hline Interval Score & Category & Amount & Category & Amount \\
\hline $26-49$ & Low & 29 & Low & 0 \\
\hline $50-73$ & Sufcient & 1 & Suficent & 17 \\
\hline $74-98$ & High & 0 & High & 13 \\
\hline $99-122$ & Very High & 0 & Very High & 0 \\
\hline
\end{tabular}

Based on the results of the pre-test and post-test, it shows that after being given learning using the IBMR learning model-based teaching materials, the students' physics problem-solving ability category increased, ranging from low to moderate and high categories. Increased ability to solve physics problem is caused by successful application of the IBMR learning model in the learning process. IBMR learning consists of 5 steps, namely orientation, investigation, multi-representation, application, and evaluation. The success of students in improving their physics problem-solving abilities races on these five steps. The first stage of the IBMR learning model is orientation, at this stage introduce the problem to students according material. At this stage teacher presents phenomena related to physics material to be studied. Application of orientation in learning can clarify the concepts that will be found (Kowalski \& Limber, 2013). Orienting students to problems can make student capable to analyze the problem, the quality of the problem, and the complexity of the problem posed (Rusman, 2014).

The second stage of the IBMR learning model is investigation, at this stage students conduct experiments according to the phenomena being studied. The investigation stage is continuous with the orientation stage, at the investigation stage the students prove scientifically the alleged answers to the problems presented at the orientation stage. The involvement of students in groups to conduct experiments to achieve physics teaching that is more effective than conventional ones (Argaw et al., 2017). Investigative activities can involve students actively in obtaining knowledge information during learning so that students are more capable the material. Students understanding to material will support students' ability to do physics problem-solving.

The third stage of the IBMR learning model is multirepresentation, at this stage students answer several questions given by the teacher regarding the results of the experiment. At this stage students are trained to make other representations in the form of verbal, graphical, or mathematical results of the data obtained from the investigation stage. Students' expertise in representation can improve understanding of the physics concepts learned and be able to solve physics problems (Siswanto, 2019; Sinaga, 2014). According to Theasy's research, et al (2017) revealed that students who have high multirepresentation abilities are can be solve physics problems with high scores.

The fourth stage in the IBMR learning model is application. At this stage, students are given exercises in solving physics problems related to the material. Physics problem-solving problems refer to physics problem-solving indicators, namely, understanding, planning solutions, solving problems, and evaluating. Difficulty of students in problem-solving in physics caused by the difficulty of students activating the knowledge they have due to the lack of practice questions so that the knowledge they have is usually not used for applications in problem solving (Lestari, 2019). Training and familiarizing students with solving physics problem problems is one way 
of getting students used to solving physics problems so that students' physics solving skills are honed and experience improvement.

The fifth stage in the IBMR learning model is evaluation. The evaluation stage is carried out directly in front of the class after students carry out the learning process and work on solving physics problems. The teacher's activity is to guide students in evaluating the process and results of solving the problems that have been given. Students independently manage the learning process until their evaluation will selfregulate and display self-efficacy, great intrinsic motivation, and high academic achievement.

\section{Problem-solving Ability Each Indicators}

The results of ability to solve physics problems when viewed each indicator, namely, understanding problem, planning solutions, solving problems and evaluating the average pretest and post-test scores of each indicator are as following in Figure 2.

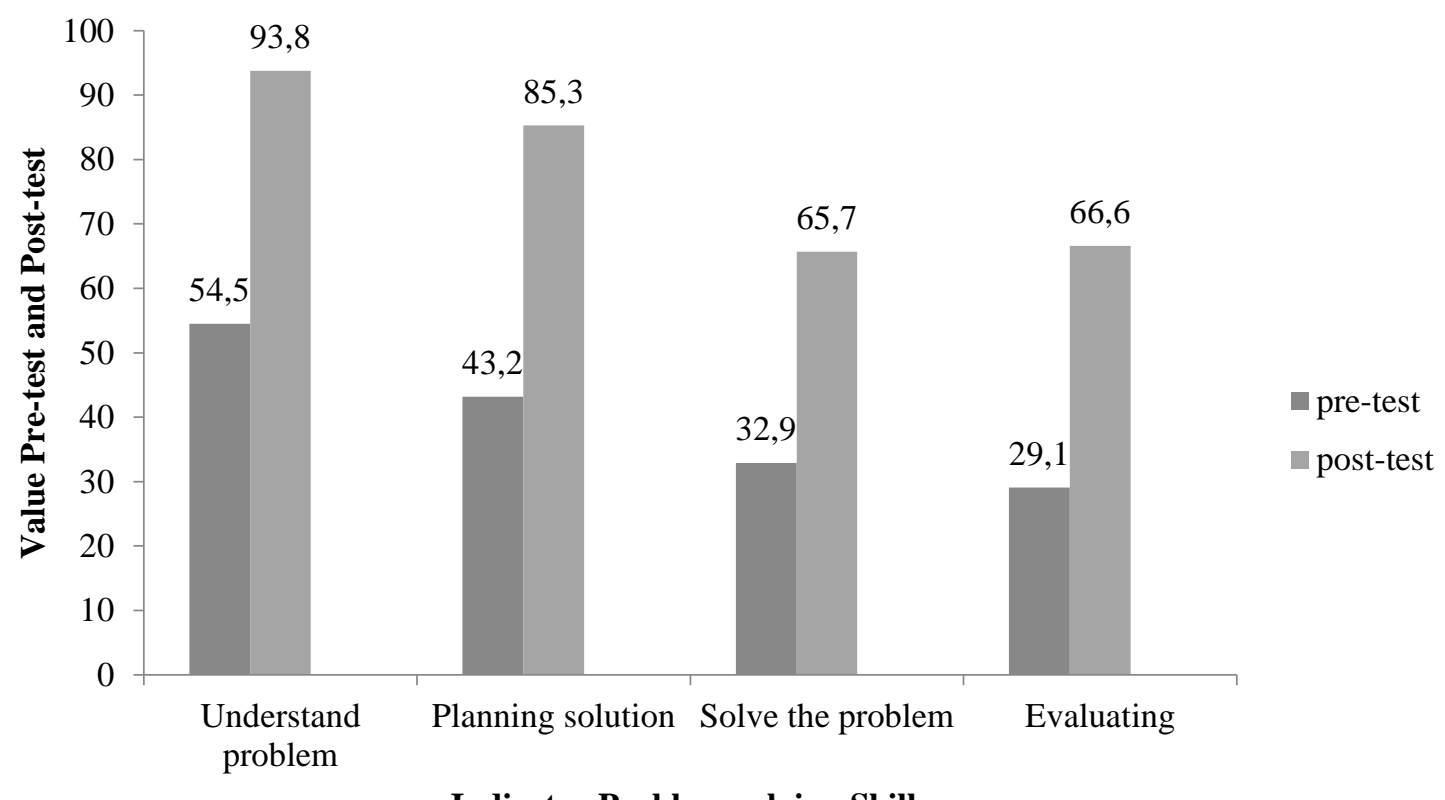

Indicator Problem-solving Skills

Figure 2. Problem-solving ability of each indicator.

Based on the results the average pre-test and post-test scores for each indicator, physics problem-solving ability after learning using the IBMR learning model has increased in each indicator. This proves that, the IBMR learning model is able to practice physics problem-solving abilities on heat meters and their displacement. The highest increase in the average score for each indicator is the understanding indicator with score 93.8, then the planning indicator for solving with score 85.3. then the evaluation indicator with score 66.6. and the lowest increase in the problem-solving indicator with score 65.7. The indicator of understanding the problem has the highest average score of all the others. This is according to the steps in solving student physics problems, can solve physics problem, when students are able to understand the questions, students will be able to identify the factors of the questions given. Indicators of understanding the problem support other indicators, students can plan problem- 
Improving Senior High School Students' Physics Problem-solving Skills Through Investigated Based Multiple Representation (IBMR) Learning Model

solving after students are able to understand the problem. When students difficulty planning solution, it will certainly heva impact againtst carrying out the plan (Mustofa, 2016). The problem-solving indicator has the lowest average score of all. This is because the students' mathematical abilities are still lacking, in fact students are already able to do according to the plan, but there are some students who are still confused about entering numbers in the equation. It can be said that students who do not provide the right solution will result problems are not resolved properly and appropriately (Pratama, 2017).

\section{Hypothesis Analysis of Influence Based on Hypothesis Testing Results} Normality Test

Table 6. Normality data.

\begin{tabular}{llccc}
\hline & \multicolumn{3}{c}{ Kolmogorov-Smirnova $^{\mathrm{a}}$} \\
\cline { 2 - 5 } & & Statistic & df & Sig. \\
\hline Physics problem- & Pre-test & .136 & 30 & .163 \\
\cline { 2 - 5 } solving skills & Post-test & .155 & 30 & .063 \\
\hline
\end{tabular}

a. Lilliefors Significance Correction

Based on the resultsof statistical calculation obtained a significance value of $0.163>$ 0.05 which means the data are normal

\section{Paired sample t-test}

The paired sample t-test aims to determine the effect of the IBMR learning model on the results of students' physics problem-solving abilities. The requirement for conducting the paired sample t-test is that the data is normally distributed, because the normality test has been carried out and the results show normal data, then the paired sample t-test can be used to test the effect of using the IBMR learning model on the ability to solve physics problems. Following are the results of the paired sample T-test in Table 7.

Table 7. T-test result.

\begin{tabular}{|c|c|c|c|c|c|c|c|}
\hline & & \multicolumn{3}{|c|}{ Paired difference } & \multirow[t]{2}{*}{$\mathbf{t}$} & \multirow[t]{2}{*}{ Df } & \multirow[t]{2}{*}{ Sig (2-t) } \\
\hline & & mean & Std-dev & Std.er mean & & & \\
\hline Pair 1 & $\begin{array}{l}\text { Pre - } \\
\text { Post }\end{array}$ & -38.114 & 6.493 & 1.186 & -32.149 & 29 & .000 \\
\hline
\end{tabular}

The conclusion from the use of paired sample t-test can be seen by comparing the value of $t$ and ttable. Based on the results of the calculation, it shows the value of tcount $-32.146<t_{\text {table }} 1.69$, which means that $\mathrm{H}_{0}$ is rejected and $\mathrm{H}_{1}$ is accepted, meaning that there is an effect of learning using the IBMR learning model on the ability to solve physics problems. This research was conducted by Siswanto et al. (2018). There was an increase in students' physics problem-solving skills after using the IBMR learning model. Based on the pre-test and post-test data obtained, it can be seen that the level of students 'physics problem-solving skills increased after learning physics was carried out using the IBMR learning model, meaning that the learning applied had an effect on students' physics problem-solving abilities. The result ability of the N-gain ability to 
solve physics problems the everage pre-test and post-test score of each indicator in Figure 3.

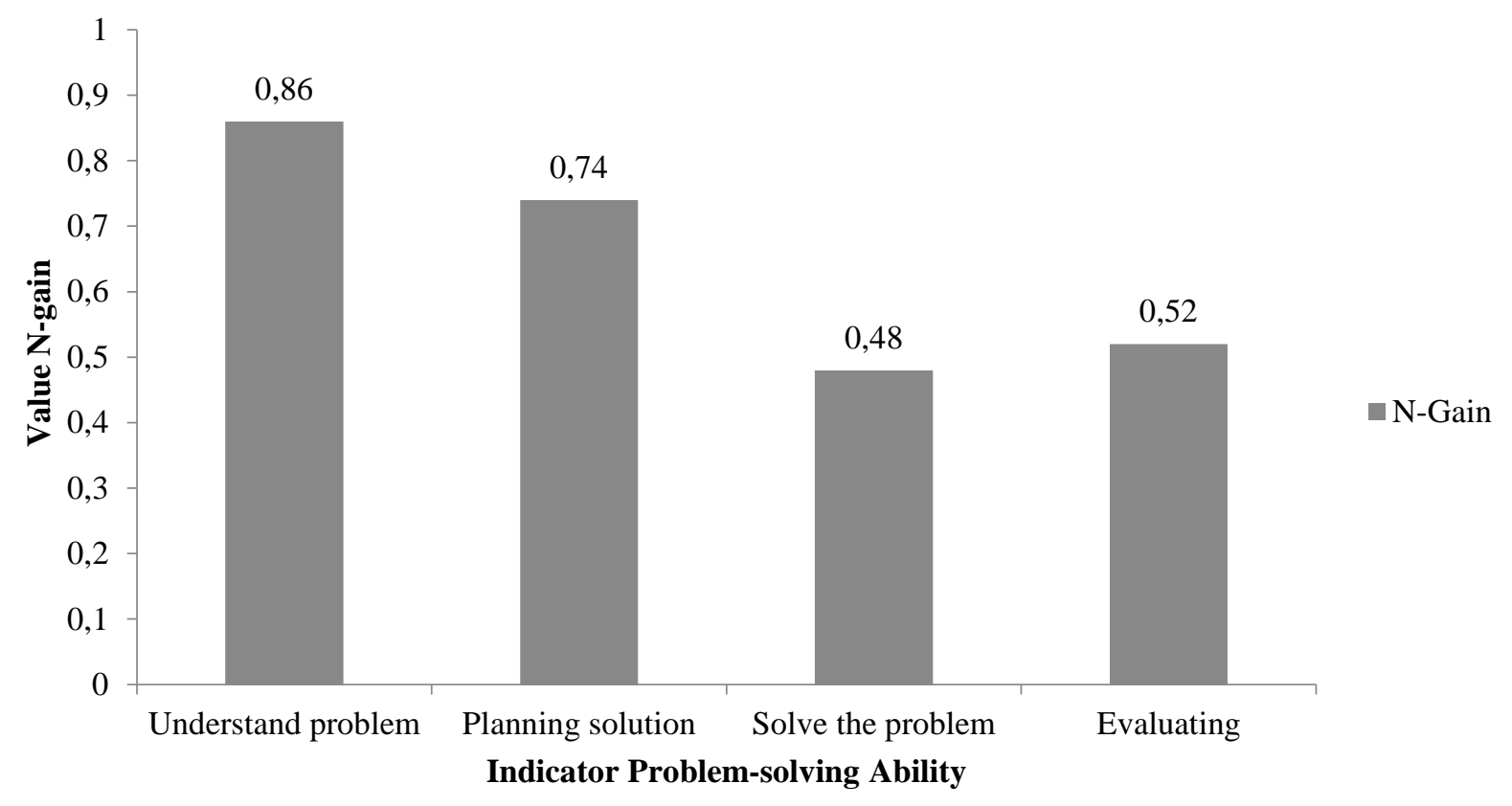

Figure 3: N-gain Score Problem-solving Ability Each Indicators

Based on the research, IBMR learning is able to practice problem-solving skills seen from the increase in the posttest score and the N-gain value in each indicator of the ability to solve physics problems. Increased problem-solving physic, the highes indicator that shows an increase seen from the N-Gain score is an indicator of understanding the problem with a score of 0.86 . then the indicator plans a solution with a score of 0.74 . then the evaluation indicator with a score of 0.52 . and the lowest oncrease in problem-solving indicator with a score of 0.48 . The average $\mathrm{N}$-gain value of the four indicators is 0.67 this means that there is an increase the ability to solve physics problems in the moderate category after learning with the IBMR learning model. These data show that most of the students when given a problem, they are able to understand problems and plan solutions to solve problems. In addition, students have been able to solve problems and, able to evaluate according to the problems given. According the research (Purnamasari et al., 2017) which shows that the indicator of understanding the problem has the highest percentage compared to indicators of other problem-solving. Based on the results, it can be concluded that at the moment working on questions related to problem-solving indicators, students feel confused in finding andcompare the similarities or differences of some of the problems given. This is what causes the indicator problem-solving has the lowest N-Gain score compared to other solving ability indicators. In general it can be concluded, the IBMR learning model can practice physics problem sloving skills. According the research of Siswanto et al. (2018) which states that learning with the IBMR learning model can improve student skills in electrical material so that IBMR learning can be used as an alternative to improve physics problem solving skills

Each stage the IBMR learning model practice physics problem-solving skill. The first step in introducing students to problems with orientation, then students doing 
experiments to prove the orientation of the problem, then students do multirepresentations to process experimental data as a basis for gaining knowledge. Furthermore, students practice solving physics problems on physics problems based on indicators of solving physics problems. Finally, students evaluate the problem-solving process carried out. Based on this explanation, the stages in the IBMR learning model are able to practice physics problem-solving skills.

\section{CONCLUSIONS}

The implementation of physics learning on heat material and its displacement used a device based on the IBMR learning model learning was able to provide good results, meaning that the IBMR learning model was able to train students' physics problemsolving abilities, especially in heat material and its displacement by showing an increase in the $\mathrm{N}$-gain score of 0.67 in the moderate category, so the learning can increase physics problem-solving ability. This research used five learning steps, they were orientation, investigation, multi-representation, application, and evaluation. Four problem-solving indicators used in this study, they were understanding the problem, planning solutions, solving problems, and evaluating. Based on the data research, it can be concluded that all indicators had increased. The stages in the IBMR learning model can make students more active in the process of acquiring knowledge so that they can train students' abilities in solving physics problems. Suggestions for further research, the teacher should review students' physics problem-solving difficulties on each indicator of problem-solving abilities before carrying out the lesson to choose the right method and model. In further research, teachers can use the IBMR learning model in practicing physics problem solving on other physics materials, and use the IBMR learning model in other lessons.

\section{REFERENCES}

Alshamali, M. A., \& Daher, W. M. (2016). Scientific reasoning and its relationship with problem-solving: the case of upper primary science teacher. Instructional of Science and Mathematics Education, 14(6), 1003-1019.

Argaw, A. S., Haile, B. B., Ayalew, B. T., \& Kuma. S. G. (2017). The effect of problem based learning (PBL) instruction on students' motivation and problem-solving skills of physics. EURASIA Journal of Mathematics Science and Technologi Education, 13(3), 857-871.

Aryawan, P., Sulastri, M., \& Seeknayasa, G. (2014). Pengaruh konseling kelompok dengan pelatihan tutor sebaya terhadap kepemimpinan siswa peserta Smansa Conseling Club (SSC) di SMA Negeri 1 Singaraja. E- Journal Undiksha Jurusan Bimbingan Konseling, 2(1), 1-10.

Azizah, R., Yuliati. L., \& Latifah, E., (2015). Kesulitan pemecahan masalah fisika pada siswa SMA. Jurnal Penelitian dan Aplikasinya, 5(2), 44-50.

Doctor, L. J., Strand., Mestre, P. J., \& Ross. H.B. (2015). Conceptual problem-solving in high school physics. Physical Review Physics Education Research, 11(2), 1-13

De Cock, M. (2012). Representation use and strategy choice in physics problem-solving. Physical Review Special Topics-Physics Education Research, 8, 020117, 1-15. 
Improving Senior High School Students' Physics Problem-solving Skills Through Investigated Based Multiple Representation (IBMR) Learning Model

Docktor, J. L., Strand, N. L., Mestre, J. P., \& Ross, B. H. (2015). Conceptual problemsolving in high school physics. Physical Review Special Topics - Physics Education Research, 11, 020106, 1-13. https:// doi.org/10.1103/PhysRevSTPER.11.020106

Eriza, A., Djudin, T., \& Mahmuda, D. (2017). Analisis kesalahan siswa dalam menyelesaikan soal tekanan zat cair SMP negeri 3 Sungai Raya. Jurrnal Pendidikan dan Pembelajaran Khatulistiwa, 6(6), 1-.

Glaze, A. L. (2018). Teaching and learning science in the $21^{\text {st }}$ century: Challenging critical assumptions in post-secondary science. Education Sciences, 8(1), 1-8. https://doi.org/10.3390/educsci8010012

Gök, T. (2015). An investigation of students' performance after peer instruction with stepwise problem-solving strategies. International Journal of Science and Mathematics Education, 13(3), 562-582. https:// doi.org/10.1007/s10763-014-9546-9

Halim, A., Yusrizal, Y., Susanna, S., \& Tarmizi, T. (2016). An analysis of students' skill in applying the problem-solving strategy to the physics problem settlement in facing AEC as global competition. Journal Pendidikan IPA Indonesia, 5(1), 1-5.

Hake, R. R. (2002). Relationship of individual student normalized learning gains in mechanics with gender, high-school physics, and pretest scores on mathematics and spatial visualization. Boise, Idaho: Physics Education Research Conference`.

Hung, C. Y., Chang, T. W., Yu, P. T., \& Cheng, P. J. (2012). The problem-solving skills and learning performance in learning multi-touch interactive jigsaw game using digital scaffolds. Proceeding of Fourth IEEE International Conference on Digital Game And Intelligent. PP. 4803-4808

Kurniawan, B. R., Handayanto, S. K., \& Parno, P. (2016). Profil kemampuan pemecahan masalah mahasiswa fisika Universitas Negeri Malang. Prosiding Seminar Nasional Pendidikan IPA Universitas Negeri Malang, Malang, pp. 105-111.

Kowalski, R. M., \& Limber, S. (2013). Psychological, physical and academic correlates of cyberbullying and traditional bullying. Journal Adolesc of Health, 5(3), S13-S20

Lestari, W. D. (2019). Kemampuan pemecahan masalah siswa dalam menyelesaikan soal cerita aljabar ditinjau dari perbedaan gender. Publikasi Program Studi Pendidikan Matematika Universitas Muhammadiyah Surakarta: 1-17

Moreno, R. (2013). Educational psycology. New York: John Wiley \& Sons Ins.

Moeed, A. (2013). Science investigation that best support student learning: Teachers' understanding of science investigation. International Journal of Environment $\mathcal{E}$ Science, 8(4), 537-559.

Mustofa, M, H., Amin. B. D., \& Rusdiana. (2016). Profil kemampuan pemecahan masalah siswa pada pembelajaran gerak lurus. Jurnal Penelitian Pengembangan Pendidikan Fisika 2(2), 15-22.

OECD. (2016). Result from PISA 2015. New York: Columbia University.

Pratama, N, D, S. A, Suyudi., Sakdiyah, H., \& Bahar, F. (2017). Analisis kesulitan siswa dalam memecahkan masalah fisika materi usaha dan energi. Jurnal Riset Pendidikan Fisika, 2(2), 82-88.

Purnamasari, I., Yuliati, L., \& Diantoro, M. (2017). Analisis kemampuan pemecahan masalah fisika pada materi fluida statis. Seminar Pendidikan IPA Pascasarjarna UM II, 5.

Rahmawati. (2016). Hasil TIMSS 2015: Diagnosa hasil untuk perbaikan mutu dan peningkatan capaian. Jakarta: Pusat Penilaian Pendidikan. 
Improving Senior High School Students' Physics Problem-solving Skills Through Investigated Based Multiple Representation (IBMR) Learning Model

Reddy, M., Vijaya, Bhaskara. B, \& Panacharoensawad. (2017). Student problem-solving difficulties and implications in physics: an empirical study on influencing factors. Journal of Education and Practice, 8(4), 59-62

Rojas, S. (2012). Enhancing the process of teaching and learning physics via dynamic problem-solving strategies: a proposal. Revista Mexicana De Fisica, 58, 7-17.

Rusman. (2014) Model-model pembelajaran: Mengembangkan profesionalisme guru. Jakarta. Rajawali Pers. PT. RajaGrafindo Persada.

Santrock, J. W. (2011). Educational psychology. New York: McGraww-Hill

Setyono, A., Nugroho, S. E. \& Yulianti, I. (2016). Analisis kesulitan siswa dalam memecahkan masalah fisika berbentuk grafik. Unnes Physics Education Journal, 5(8), 32-39.

Sinaga, P., Suhandi, A., \& Liliasari, L. (2014). The effectiveness of learning to represent physics concept approach: preparing pre-service physics teachers to be good teachers. International Journal of Research in Applied, Natural and Social Sciences, 2(4), 127-136.

Sujarwanto, E., Hidayat, A., \& Wartono. (2014). Kemampuan pemecahan masalah fisika dengan modeling instruction pada siswa SMA kelas XI. Unnes Physics Education Journal, 3(1), 65-78

Siswanto, J., Endang, S., \& Jatmiko, B. (2018). Practicality and effevtiveness of the IBMR teaching model to improve physics problem-solving skills. Jounal of Baltic Science Education, 17(3), 381-394

Siswanto, J. (2019). Implementasi model IBMR berbantu PhET simulation untuk meningkatkan kemampuan representasi pada pembelajaran fisika. Jurnal Penelitian Pembelajaran Fisika, 10(2), 96-100.

Theasy, Y., Wiyanto., \& Sujarwata. (2017). Multi-representation ability of students on the problem-solving physics. International Conference on Mathematics, Science, and Education, 1-4.

\section{${ }^{*}$ Dyah Ayu Setyarini, M.Pd. (Corresponding Author)}

Universitas Negeri Surabaya,

Postgraduate Programe, Continuing Program Development, Jl. Unesa Lidah Wetan Surabaya, Indonesia

Email: dyah.18015@mhs.unesa.ac.id

\section{Dr. Z.A. Imam Supardi, M.Si}

Universitas Negeri Surabaya,

Postgraduate School, Continuing Program Development, Jl. Unesa Lidah Wetan Surabaya, Indonesia

Email: zsupardi@gmail.com

\section{Dr. Elok Sudibyo, M.Pd}

Universitas Negeri Surabaya,

Postgraduate School, Continuing Program Development, Jl. Unesa Lidah Wetan Surabaya, Indonesia

Email: eloksudibyo@unesa.ac.id 